\title{
Słowik Kanta, słowik Andersena i mimesis Adorna. Esej śladem XVIII- i XIX-wiecznej prehistorii kilku wątków Teorii estetycznej
}

\author{
Jakub Chachulski \\ https://orcid.org/0000-0002-8972-1490
}

Esej koncentruje się na niektórych aspektach teorii estetycznej Theodora W. Adorno jako szczególnego rodzaju reinterpretacji kantowskich i romantycznych idei piękna naturalnego. Osią przeprowadzonej refleksji jest motyw śpiewu słowika jako paradygmatu piękna natury, wprowadzony przez Kanta w Krytyce władzy sądzenia, i jego reinterpretacja w znanej baśni Hansa Christiana Andersena - oba przywołane w tym samym akapicie pracy Adorna. Napięcie między tymi przeciwstawnymi ujęciami rozpoznane zostaje jako utrzymujące się głęboko w myśli estetycznej frankfurckiego filozofa, szczególnie w kontekście jego kluczowych koncepcji pozoru estetycznego i mimesis.

Słowa kluczowe: Immanuel Kant, Theodor W. Adorno, piękno naturalne, mimesis, pozór estetyczny

O ile obfitą obecność autora Krytyki władzy sądzenia na kartach estetycznego opus magnum Theodora W. Adorna trudno uznać za okoliczność niezwykłą, pojawiające się choćby i jednokrotnie nazwisko Hansa Christiana Andersena obudzić już może niejakie zaciekawienie - tym bardziej gdy, jak ma to miejsce, duński pisarz przywoływany jest nie jako twórca przedmiotów estetycznego namysłu

JAKUB CHACHULSKI, dr, Instytut Sztuki PAN; adres do korespondencji: ul. Długa 28, 00238 Warszawa; e-mail: jakub.chachulski.ispan.pl 
frankfurtczyka, lecz jako uczestnik prowadzonej dyskusji, a nawet swoisty głos korygujący w stosunku do tez królewieckiego myśliciela.

Bezpośrednim powodem spotkania filozofa i baśniopisarza na kartach Teorii estetycznej jest figura słowika - a właściwie słowiczego śpiewu - jako upostaciowienia piękna naturalnego, użyta przez Kanta we wpływowej ilustracji zawartej w trzeciej Krytyce, przez duńskiego pisarza zaś w słynnej baśni o ptaku prawdziwym, ptaku mechanicznym i chińskim cesarzu. Choć kantowsko-andersenowski wątek przywołany jest przez Adorna w dość wąsko zakreślonym kontekście rozważań o relewantności genezy dzieła sztuki dla doświadczenia estetycznego, kreśli on zarazem jedną z żywotnych linii refleksji nad stosunkiem piękna naturalnego i piękna sztuki, istotną jako pewna tradycja filozoficzna leżąca u podłoża myśli estetycznej frankfurtczyka.

Tym ciekawsze okazać się może prześledzenie tego słowiczego tropu, że specyficzny i z reguły niełatwy w odbiorze styl pism Adorna odnotowuje swe zapożyczenia i inspiracje $z$ reguły skrótowo i enigmatycznie, często traktując je jako rzecz oczywistą i niewartą uwagi. Fakt, iż woli Adorno przejęte skądinąd pojęcia i koncepcje puszczać w ruch nie troszcząc się zbytnio o ich wcześniejsze zdefiniowanie, jak też fakt, że poszczególne inspiracje i zapożyczenia często u niego nakładają się i krzyżują, pozwala posłużyć się lubianą przez frankfurtczyka metaforą sedymentu: wiele pojęć z pozoru oczywistych i jednoznacznych faktycznie ukrywa pod sobą nawarstwione pokłady wcześniejszych kontekstów, ujęć i sporów; swoiste historie i prehistorie, bez świadomości których lektura pism frankfurckiego myśliciela staje się trudna, a czasem jałowa. Nieśpieszna wędrówka tropem kantowsko-andersenowskiego słowika w głąb Teorii estetycznej, choćby i okazać się miała dość fragmentarycznym naświetleniem kilku jedynie wątków gęstego splotu myślowego ostatniej, pośmiertnie wydanej pracy frankfurtczyka, nie wydaje się czasem straconym.

W Krytyce władzy sądzenia figura słowika i jego imitacji pojawia się w momencie, gdy królewiecki filozof, dowodząc wyższości piękna naturalnego nad pięknem sztuki, odwołuje się do pojęcia bezpośredniego zainteresowania estetycznego. Gdy sąd smaku bierze za swój przedmiot wytwór natury, pociąga za sobą u postrzegającego afirmację samego istnienia przedmiotu: „i nie chciałby, aby nie 
istniały one [podziwiane przedmioty - J.Ch.] w przyrodzie w ogóle, choćby i doznawał wskutek tego pewnej szkody, a na pewno nie spodziewał się żadnej po nich korzyści”" Wytwór przyrody podoba się nie tylko „ze względu na swą formę”: podoba się sam fakt jego istnienia. Nieodzownym jednak tego warunkiem jest przekonanie obserwatora, że ma do czynienia z pięknem natury właśnie, nie z wytworem sztuki - i ten warunek unaocznia Kant interesująca nas anegdotą:

Cóż bardziej wielbią poeci niż czarownie piękne trele słowika w samotnych krzakach w cichy wieczór letni przy łagodnym świetle księżyca? Znane są jednak przykłady, że w braku takiego śpiewaka, jakiś krotochwilny gospodarz gości swych, którzy przybyli do niego, aby rozkoszować się wiejskim powietrzem, wyprowadził ku ich najwyższemu zadowoleniu w pole w ten sposób, że ukrył w krzaku swawolnego chłopaka, który umiał (za pomocą trzciny czy rurki w ustach) naśladować te trele w sposób zupełnie podobny do przyrody. Wystarczy jednak stwierdzić, że jest to oszustwo, i nikt nie potrafi dłużej przysłuchiwać się śpiewowi, który przedtem uważał za tak powabny [...]. Abyśmy mogli żywić bezinteresowne zainteresowanie w pięknie jako takim, musi ono być przyrodą, albo musimy je za nią uważać

Nieco wcześniej znaleźć można paralelną ilustrację: miłośnik piękna przyrody tym razem wprowadzony zostaje w błąd przez powtykane w ziemię sztuczne kwiaty, „zupełnie podobne do naturalnych”, i kunsztownie rzeźbione ptaki poustawiane na gałęziach drzew; skoro jednak dostrzeże swój błąd, w jednej chwili „bezpośrednie zainteresowanie” ustępuje miejsca refleksji o użytku, jaki zrobić można by z owych imitacji - chociażby ozdabiając nimi mieszkanie ${ }^{3}$.

Fakt, iż przypuszczenie kończące tę drugą ilustrację dość ławo daje się poddać w wątpliwość, nie przekreśla jej zasadniczego sensu, w zarysie identycznego $\mathrm{z}$ historią o słowiku. Owszem, z chwilą odkrycia podstępu estetyczna kontemplacja równie dobrze, a może i lepiej zamienić mogłaby się w podziw dla kunsztowności wykonania imitacji; tak czy inaczej jednak estetyczne doświadczenie przyrody w swojej integralności zostaje bezpowrotnie rozbite - i to niezależnie od tego na ile obserwowane „piękno form” może pozostać bez zmiany.

Ów nieredukowalny naddatek zapewniający pięknu naturalnemu wyższość nad pięknem sztuki zawsze i niezależnie od stopnia upodobania w „pięknie

\footnotetext{
${ }^{1}$ Immanuel Kant, Krytyka władzy sądzenia, tłum. Jerzy Gałecki (Warszawa: PWN, 1986), 218.

${ }^{2}$ Tamże, 223-224.

${ }^{3}$ Tamże, 218-219.
} 
formy” - sam Kant przyznaje, że pod tym względem sztuka nieraz prześciga naturę - wypływać ma wprost z konstytutywnej dla kantowskiego ujęcia piękna koncepcji „celowości formalnej” czy też „celowości bez celu”. Ta - używając terminologii Kanta - „celowość subiektywna” zasadza się na harmonijnej odpowiedniości naoczności i intelektu, w odróżnieniu od „celowości obiektywnej”, zawierającej $\mathrm{w}$ sobie odniesienie do pojęcia, a więc porównującej rzeczywisty przedmiot $\mathrm{z}$ tym czym winien on być. Formuła „celowości bez celu” oznacza wykluczenie odniesienia przedmiotu do jakiegokolwiek uprzedniego i zewnętrznego zamiaru, pojęcia, czy wzorca. Prawdziwą, nie fingowaną tego rodzaju „celowość formalną” odnajduje Kant jedynie w przyrodzie, pozostawiając sztuce wysoce niezadowalającą alternatywę: bądź budzić ona będzie zainteresowanie estetyczne poprzez czyste złudzenie piękna naturalnego - a wówczas to to drugie przecież jest rzeczywistym obiektem owego zainteresowania - bądź też „celowo i wyraźnie zmierza do wywołania naszego upodobania”, co zapośrednicza zainteresowanie estetyczne, jako motywowane określonym zamiarem i nakierowane na pewien zewnętrzny cel ${ }^{4}$.

Celność kantowskiego ujęcia leży w fakcie, iż pozwala ono oddać sprawiedliwość specyfice doświadczenia estetycznego jako subiektywnego, nie zapośredniczonego przez pojęcia i opartego na zmysłowej naoczności, zarazem nie dając mu osunąć się w czyste doznanie zmysłowe czy przyjemność płynącą ze śledzenia pozbawionej głębszego znaczenia gry. Z drugiej strony jednakże kluczowe dla kantowskiej teorii pojęcie „bezpośredniego zainteresowania estetycznego” zdaje się prowadzić niebezpiecznie blisko konstatacji, iż w samej intencji stworzenia dzieła sztuki tkwi pewna nieusuwalna aporetyczność, jaka nieodwołalnie wiązać się musi z pragnieniem zrobienia czegoś, co - z definicji niejako - zrobione być nie może.

\section{II}

Czy jednak kantowska konkluzja z jej przeciwstawieniem natury i sztuki jest jedyną możliwą interpretacją przytoczonej przez królewieckiego filozofa historii o słowiku? Czy dezintegracja doświadczenia estetycznego nie daje się wyjaśnić inaczej? Może chodzi tu tylko o bardziej ogólne kategorie „imitacji” i „oryginału”?

${ }^{4}$ Tamże, 222. 
Albo o „autentyczność” jako słabszą postać „naturalności”, niekoniecznie związaną z ostrym odgraniczeniem świata natury od świata człowieka?

Jest faktem, że opisane przez Kanta estetyczne rozczarowanie - zapożyczam ten termin z poświęconego kantowskiemu słowikowi eseju Jerome Langgutha ${ }^{5}$ daje się w jakiejś mierze wyjąć $\mathrm{z}$ ram systemu królewieckiego myśliciela i zuniwersalizować. Wspomniany autor z powodzeniem konstruuje przykłady sytuacji, w których dojść mogłoby do podobnego zdarzenia: pozorną improwizację, która okazuje się uprzednio napisana i wyćwiczona, czy fotografię, która okazuje się fotomontażem. Wspólny mianownik, jaki odnajduje on w tych i innych przykładach, wyłożyć można następująco: świadomość, iż rzekome dzieło sztuki zostało w ten czy inny sposób „sfabrykowane” odcina charakterystyczną dla dzieła sztuki możliwość budowania wielu różnorodnych interpretacji dzieła, wysuwając na pierwszy plan problem zewnętrznego względem percypowanego przedmiotu wyjaśnienia jak też i na kształt czego został on zrobiony.

Przyjmując to wyjaśnienie, nie oddalamy się znowu tak bardzo od Kanta. Owszem, pisze on wyraźnie, że sztuka, aby okazać się piękną, może i musi naśladować charakterystyczną dla przyrody „celowość bez celu”. Inne z ujęć kantowskich mówi o „swobodnej grze” intelektu czy też o harmonijnym przenikaniu się naoczności z intelektem. Nieco bardziej potocznie i opuszczając teren kantowskiej terminologii można by powiedzieć, iż piękny przedmiot przejawiać winien pewnego rodzaju „sensowność” nie krzepnącą jednakże w pojęciowo dany sens. „Postawa interpretacyjna” Langgutha odpowiada takiej właśnie kontemplacji, angażującej intelekt lecz nie zwieńczonej ostatecznym, możliwym do pojęciowego ujęcia zrozumieniem.

Istotna różnica polega jednak na tym, że królewiecki filozof stawia tu nieprzekraczalną granicę: jedynie pięknu natury „celowość bez celu” przysługuje rzeczywiście i bez zastrzeżeń, dzieło sztuki jedynie ją pozoruje, przybierając - złudnie - kształt „tak wolnego od wszelkiego przymusu arbitralnych prawideł, jak gdyby było ono dziełem samej przyrody"6. Rozpatrując przykłady podane przez Langgutha w oderwaniu od systemu Kanta, można by zaproponować jakieś bardziej uniwersalne pojęcie - w zależności od dokładniejszej interpretacji moglibyśmy je nazwać na przykład „estetyczną autentycznością” lub „pozorem spontaniczności” -

\footnotetext{
${ }^{5}$ Jerome Langguth, „Kant Nightingale: Aesthetic Disappointment as Loss of Interpretive Richness", http://www.academia.edu/4055373/Kants_Nightingale (dostęp: 17.08.2020).

${ }^{6}$ Kant, Krytyka władzy sądzenia, 229.
} 
nie tylko nieodłączne od każdego doświadczenia estetycznego, ale także pozbawione kantowskiej absolutności, w tym sensie, iż cecha taka mogłaby przysługiwać dziełu pod jednym względem, a zarazem nie przysługiwać pod innym, jak w przypadku improwizacji, tracącej swój specyficzny czar z chwilą, gdy słuchacze orientują się iż została ona uprzednio opracowana, a jednak nadal dającej się z przyjemnością słuchać jako wykonanie uprzednio napisanego utworu. Co więcej, następująca $w$ rozważanych sytuacjach dezintegracja doświadczenia estetycznego nie jest tak nieodwracalna, jak mogłoby się wydawać - świadomość, że większość wydawanych dzisiaj nagrań jest produktem montażu graniczącego już nieraz z cyfrowym syntetyzowaniem dźwięku, dzięki czemu osiąga nieskazitelność praktycznie niedostępną w rzeczywistych wykonaniach, zasadniczo nie przeszkadza nam delektować się nimi.

Wolno jednak zapytać, czy taka uniwersalizacja problemu nie oznacza zarazem jego częściowej neutralizacji, jako że zamyka nas ona w granicach wąsko rozumianego doświadczenia estetycznego - faktycznie interesuje nas już tylko to, czy percypowany przedmiot prezentuje się jako powstały z quasi-naturalną, niecelową czy też nie-instrumentalną spontanicznością. Tym samym tracimy z oczu ontyczną ważkość piękna, celnie ujętą w kantowskiej koncepcji bezpośredniego zainteresowania.

Z drugiej strony, konstruowane przez Langgutha przykłady „estetycznego rozczarowania”, analogiczne do kantowskiej historii o słowiku, lecz niezwiązane z pięknem naturalnym, mogą także prowadzić do poddania w wątpliwość kantowskiego rozgraniczenia pomiędzy pięknem przyrody a pięknem sztuki. Faktycznie da się to zrobić nie naruszając zasadniczych zrębów kantowskich analiz estetycznych, choć biorąc w nawias bardziej podstawowe założenia jego systemu: należałoby jedynie uznać, iż w określonych warunkach artystę - czy przynajmniej jego twórczość (w sensie działania, nie przedmiotu) - przenieść można na druga stronę postawionej granicy uznając, iż przemawia przez niego sama natura. Królewiecki filozof nie przeoczył tego tropu i uwzględnia go, w jakiejś mierze, wprowadzając pojęcie nieświadomie działającego geniuszu jako elementu „przyrody w podmiocie" " Rozwiązanie to jednakże, koegzystując z podstawowym znaczeniem, jakie przyznaje Kant nieprzekraczalnej opozycji podmiot-przedmiot, czy koncepcją „bezpośredniego zainteresowania estetycznego” pozostaje w całości systemu

${ }^{7}$ Tamże, 232. 
swoistym ciałem obcym, czy też, jak ujmuje to później Adorno, „miejscem schronienia" dla tego, co nie dopuszczane przez system ${ }^{8}$.

Można jednakże wskazać na myśl nieco wcześniejszą - autor jej zmarł na trzy lata przed ukazaniem się pierwszego wydania Krytyki czystego rozumu - o wpływie porównywalnym $\mathrm{z}$ kantowskim, która problem ten stawia $\mathrm{w}$ istotnie innym świetle. Wyobraźmy sobie inną jeszcze paralelę dla królewieckiego słowika. Miast ptaszka ukrytego w krzakach mamy oto wiejskiego pastuszka z wierzbową fujarką i zasłuchanych w jego grę miejskich gości; po bliższym jednak zbadaniu sprawy wychodzi na jaw, iż to nie wiejski chłopak, grający jak mu serce dyktuje bezimienne melodie, od niepamiętnych czasów z ust do ust podawane, lecz naśladujący go profesjonalny flecista. To już nie słowik królewiecki, rzecz oczywista, lecz słowik Jana Jakuba, a nieprzekraczalna granica oddzielająca człowieka od przyrody ustąpiła miejsca płynniejszej granicy pomiędzy nieszczęśliwym człowiekiem cywilizowanym a „szlachetnym dzikusem”. Głos serca przemawiający poprzez dźwięki fujarki Rousseau to głos samej natury, po kantowsku wolnej od zewnętrznego przymusu racjonalności celu, zamiaru czy pojęcia.

Szeroko spopularyzowane ujęcie Rousseau, choć w sferze profesjonalnej filozofii nie tak może jak kantowskie wpływowe, w pierwszej fazie romantyzmu było praktycznie wszechobecne i wszechprzenikające; jego echo bez trudu da się dosłyszeć w kolejnej inkarnacji historii o słowiku, w pół wieku po Kancie, w baśni Hansa Christiana Andersena9. Tu słowik jest oczywiście, jak u Kanta, słowikiem, ale jednocześnie figurą artysty (jak powiadają andersenolodzy, zarówno samego autora jak i szwedzkiej śpiewaczki Jenny Lindt ${ }^{10}$ ). Zamiast ludzkiej imitacji ptakowi przeciwstawiona jest mechaniczna pozytywka, dzięki czemu zaciera się podstawowe u Kanta przeciwstawienie świata człowieka i świata przyrody: prawdziwy

${ }^{8}$ Theodor W. Adorno, Teoria estetyczna, tłum. Krystyna Krzemieniowa (Warszawa: PWN, 1994), 312-313.

${ }^{9}$ Nie znam dowodów przemawiających za świadomym nawiązaniem Andersena do kantowskiej Krytyki, choć tak zdaje się uważać Adorno. Szeroką popularnością cieszył się motyw kantowskiego słowika za sprawą F. Schillera, który odwołał się do kantowskiej anegdoty w rozprawie O poezji naiwnej i sentymentalnej, w: Friedrich Schiller, Listy o estetycznym wychowaniu człowieka i inne rozprawy, tłum. Irena Krońska, Jerzy Prokopiuk (Warszawa: Czytelnik, 1972), 306-307.

${ }^{10}$ Por. Anna Harwell Celenza, Hans Christian Andersen and Music: The Nightingale Revealed (London - New York: Ashgate, 2017), 60-62. Jeśli rzeczywiście, jak pisze autorka, Słowik pomyślany był wprost jako apologia naturalnego śpiewu Lindt przeciwstawionemu sztucznej wirtuozerii włoskich śpiewaczek operowych, pokrewieństwo baśni z muzycznymi wątkami myśli Rousseau stawałoby się jeszcze bliższe. 
słowik reprezentuje spontaniczność, naturalność i prostotę prawdziwego artysty, podczas gdy automat obrazować ma twórczość opartą na mechanicznym naśladownictwie i sztucznej ozdobności. Konstrukcja ta podparta jest wyartykułowanym w warstwie dosłownej baśni źródłowo pochodzącym od Roussea toposie mówiącym o uczestnictwie prostego ludu w świecie przyrody i niewrażliwości na naturalne piękno wyrafinowanych przedstawicieli wysokiej rzekomo kultury, zdolnych jedynie zachwycać się mechaniczna wirtuozerią i powierzchownym blichtrem oraz powtarzać zasłyszane oceny.

O ile transformację ujęcia kantowskiego w popularny wczesnoromantyczny „russoizm” niekoniecznie uznać należałoby za krok naprzód z punktu widzenia filozoficznej refleksji, przyznać trzeba zarazem, iż z obsadzenia mechanicznej pozytywki w roli kantowskiego rzemieślnika-naśladowcy wypływa kilka przenikliwych intuicji dotyczących charakteru piękna naturalnego, które istotnie rozwijają analizy królewieckiego filozofa. Mechaniczny słowik nie może śpiewać w duecie z prawdziwym, który śpiewając „z serca” za każdym razem śpiewa inaczej: natura nie zna idealnych powtórzeń, stąd jej dokładna kopia dyskwalifikuje samą siebie. Logika duplikatu jest obcą naturze logiką instrumentalnej, racjonalnej celowości. Po drugie, sztuczny słowik musi być nakręcany: mechaniczne naśladowanie zakłada rozdzielenie odzwierciedlającej przyrodę formy oraz tworzącej ją i wprawiającej w ruch energii, gdy w przyrodzie - znów po kantowsku - piękna forma jest spontanicznym, quasi-przypadkowym wykwitem stojącej za nią ślepej siły życia i wzrostu.

\section{III}

Spójrzmy więc, jaki użytek czyni ze słowiczego toposu Adorno. Interesujący nas passus Teorii estetycznej pojawia się w kontekście problemu istotności a właściwie nieistotności - genezy dla dzieła sztuki i brzmi następująco:

Przypomnijmy morał o rzeczywistym i naśladowanym słowiku z Krytyki władzy sądzenia, motyw sławnej baśni Andersena, wielokrotnie opracowywany jako opera. Rozważanie, w którym Kant nawiązuje do tego, podstawia znajomość powstania fenomenu w miejsce doświadczenia tego, czym on jest. Przyjmując, że wymyślony chłopak potrafił rzeczywiście tak dobrze naśladować słowika, iż nie można było uchwycić różnicy, powoływanie się na autentyczność czy nieautentyczność fenomenu staje się obojętne, chociaż trzeba przyznać Kantowi, że tego rodzaju wiedza 
zabarwia doświadczenie estetyczne: inaczej widzi się obraz, znając nazwisko malarza. Żadna sztuka nie obywa się bez takich przesłanek, a tych przesłanek równie nie da się z niej wyeliminować, jak wyprowadzić ją z nich jako coś koniecznego. Andersen kierował się dobrym instynktem, kiedy zamiast Kantowskiego rzemieślnika użył pozytywki; opera Strawińskiego charakteryzuje to, co się z niej wydobywa jako mechaniczne rzępolenie. Różnica [oddzielająca przejaw] od śpiewu naturalnego jest słyszalna w przejawie: gdy tylko artefakt chce budzić iluzję naturalności - zawodzi ${ }^{11}$.

Tenor tego nie tyle może $\mathrm{w}$ istocie enigmatycznego, co raczej zaciemnionego swobodnym i lekko dygresyjnym duktem fragmentu streścić można by następująco: Adorno zarzuca Kantowi „podstawienie znajomości powstania fenomenu w miejsce doświadczenia tego, czym on jest” (choć jednocześnie nieco osłabia swój zarzut przyznaniem, iż tego rodzaju przed-wiedza rzeczywiście zabarwia doświadczenie i nie da się tego faktu usunąć, choć pozostaje on zjawiskiem pobocznym) po to tylko, by wbrew niedoskonałości kantowskiej anegdoty wzmocnić zasadniczą tezę królewieckiego filozofa: rozdział piękna naturalnego od piękna sztuki jest tak ostateczny, że żadna imitacja nie jest możliwa, różnica zawsze będzie naocznie uchwytna. Stąd uznanie Adorna dla intuicji Andersena, zastępującego rzemieślniczo kunsztowne, udane aż do nieodróżnialności naśladownictwo „rzępoleniem” mechanicznej imitacji.

Wolno jednak zapytać, czy nie zadaje tu sobie Adorno niepotrzebnego poniekąd trudu. Winna jest przecież chyba nie tyle kantowska anegdota, co jej interpretacja: czy ta pierwsza rzeczywiście „podstawia znajomość powstania fenomenu w miejsce doświadczenia tego, czym on jest"? Weźmy na początek drugi przykład

${ }^{11}$ Adorno, Teoria Estetyczna, 326-327. Tłumaczenie tego fragmentu podaję w wersji nieco poprawionej, wg oryginału: „Erinnert sei an die wirkliche und die imitierte Nachtigall aus der Kritik der Urteilskraft, das Motiv des berühmten, vielfach veroperten Märchens von Andersen. Die Betrachtung, die Kant daran anknüpft, substituiert die Kenntnis der Entstehung des Phänomens anstelle der Erfahrung dessen, was es ist. Gesetzt, der fingierte Bursche vermöchte tatsächlich, die Nachtigall so gut nachzuahmen, daß kein Unterschied zu hören wäre, so verurteilte das den Rekurs auf die Authentizität oder Nicht- Authentizität des Phänomens zur Gleichgültigkeit, obwohl Kant einzuräumen wäre, daß derlei Wissen die ästhetische Erfahrung färbt: man sieht ein Bild anders, wenn man den Namen des Malers kennt. Keine Kunst ist voraussetzungslos, und ihre Voraussetzungen lassen aus ihr so wenig sich eliminieren, wie sie aus ihnen als Notwendiges folgte. Andersen hat mit gutem Instinkt anstatt des Kantischen Handwerkers ein Spielwerk bemüht; Strawinskys Oper charakterisiert, was es ertönen läßt, als mechanisches Gedudel. Die Differenz vom natürlichen Gesang wird am Phänomen hörbar: sobald das Artefakt die Illusion des Natürlichen erwecken will, scheitert es.” Theodor W. Adorno, Ästhetische Theorie (Berlin: Suhrkamp, 1973), 267. 
z Krytyki władzy sądzenia, to jest umieszczoną na gałęzi „kunsztownie rzeźbioną” figurkę ptaka. Co przesądza o rozpoznaniu mistyfikacji? Nieruchomość wyrzeźbionego ptaka, oczywiście. Nie dzieje się to jednak od razu: w pierwszym momencie zostaje ona zinterpretowana jako tak charakterystyczna dla zwierzęcia chwila znieruchomienia, zawierająca już w sobie niejako możliwość nagłego ruchu, z błyskawicznym zerwaniem się do lotu włącznie. Co istotniejsze jednak, te dwa rodzaje nieruchomości odróżniają się od siebie w samym doświadczeniu, nie w refleksji nad nim: widzimy ptaka jako coś-nieskończenie-ruchliwego-co-tylko-namoment-zastygło-w-bezruchu, gdy jednak uświadomimy sobie mistyfikację, widzimy już co innego. Adorno pozostaje tu w tyle za analizami fenomenologów: doświadczenie transcenduje to, co naocznie dane, „dopowiadając” sobie niejako brakujące elementy. Nie inaczej jest ze śpiewem słowika: obecność niewidocznego ptasiego śpiewaka pozostaje, używając terminologii fenomenologów, efektywnym składnikiem doświadczenia.

Naoczność genezy piękna naturalnego w obrębie jego estetycznego doświadczenia pociąga za sobą różnicę tegoż doświadczenia od doświadczenia sztuki nie tylko pod względem zawartości (tego, co dane), ale i samej struktury doświadczenia. Wytwór przyrody nie odcina się od swojej genezy jako odgraniczona całość: to właśnie zdaje się mieć na myśli Kant pisząc, iż sztuka ma się do przyrody jak „robienie czegoś” (facere) do „czynności w ogóle” (agere), zaś ich wytwory jak „dzieło” (opus) do „skutku” (effectus) ${ }^{12}$. W tym sensie doświadczenie piękna przyrody nigdy nie wyodrębnia do końca swojego przedmiotu, jego granice są nieostre: w jakimś sensie dana jest zawsze całość przyrody - choć nie jako sam przedmiot, to i nie jako jedynie pasywne tło, lecz raczej jak coś, co aktywnie wyłania z siebie ten czy inny konkretny obiekt doświadczenia. Adorno ujmuje to, mówiąc o pięknie przyrody jako „przejawie”, którego „uprzedmiotowienie” w drodze imitacji skutkuje zarazem likwidacją ${ }^{13}$ i nieco dalej twierdząc, niczym ortodoksyjny kantysta, iż odbywające się w sztuce "podwojenie” piękna naturalnego pozbawia go właśnie „owego bycia samoistnego, którym żywi się doświadczenie przyrody"14.

\footnotetext{
${ }^{12}$ Kant, Krytyka władzy sądzenia, 224.

${ }^{13}$ Adorno, Teoria estetyczna, 124.

${ }^{14}$ Tamże, 125.
} 


\section{IV}

W przytoczonym fragmencie nie chodzi jednak frankfurckiemu filozofowi zasadniczo o dosłowne naśladowanie natury, lecz o owo specyficzne dla sztuki upodobnienie: dzieło winno prezentować się jako nie „zrobione” lecz „po-prostuistniejące”, na kształt zjawiska przyrody. Teza ta przewija się przez całą spuściznę estetyczną frankfurtczyka jako prawda podstawowa i nie wymagająca uzasadnienia, często przybierając urzekająco poetyckie postaci: „[...] wersy, które brzmią nie tak jak gdyby pochodziły od niego [poety S. Georgego - J.Ch.], ale jak gdyby były tu już od początku świata i musiały być zawsze takimi”"15.

Idea ta znajduje swój pełny wyraz w adornowskiej koncepcji pozoru estetycznego, przewrotnie - bo wbrew intencji pisarza przywracając andersenowskiej parze śpiewaków pierwotne kantowskie konotacje - rozwijającej to, co implicite obecne w baśni: dzieło sztuki potrzebuje interwencji instrumentalnej, quasi-mechanicznej racjonalności - choć obróconej przeciw sobie: Adorno mówi tu o „quasi-racjonalności”, racjonalności „metaforycznej”, „odwróconej” czy też wreszcie „racjonalności, która stała się estetyczna” - aby „samo w sobie, a nie poprzez imitację” zbliżyć się do „czegoś naturalnego"16. Podczas gdy dosłowna imitacja natury denuncjuje samą siebie, immanentna logika (udanego) dzieła, w której giną ślady władczej ingerencji podmiotu, zdolna jest nadać mu pozór quasi-naturalnej całości, której części składowe spojone zostają mocą własnej dynamiki, całości jawiącej się jako - powróćmy do kantowskiego sformułowania - tak wolna od wszelkiego przymusu, jak gdyby była dziełem samej przyrody ${ }^{17}$. Nauka płynąca z kantowskiej opowieści o słowiku pozostaje jednak w mocy; dzieło sztuki tyleż naśladuje naturę w jej „niecelowej celowości”, co odcina się od niej jako skończone, zamknięte - jako „dzieło” właśnie. Zamkniętość artefaktu pozostaje dialektycznie dwuznaczna: $\mathrm{z}$ jednej strony równoznaczna jest $\mathrm{z}$ odcięciem od świata będącym znamieniem „sztuczności” w sensie wyłożonym powyżej, zarazem jednak oznacza zwarcie się dzieła w monadę będącą „światem w sobie”, imitującą wewnątrz siebie

${ }^{15}$ Theodor W. Adorno, O liryce i społeczeństwie, w: Theodor W. Adorno, Sztuka i sztuki. Wybór esejów, red. Karol Sauerland, tłum. Krystyna Krzemień-Ojak (Warszawa: PIW, 1990), 167.

${ }^{16}$ Adorno, Teoria Estetyczna, 122.

${ }^{17} \mathrm{O}$ tym, że Adorno z pełną świadomością, explicite wyjmuje kantowską formułę o „niecelowej celowości” naturalnego piękna z kontekstu systemu królewieckiego filozofa por. Adorno, Teoria Estetyczna, 254. 
„niecelową celowość” natury. Monadyczne dzieła sztuki „w swoim zamkniętym obszarze przedstawiają to, co pozostało na zewnątrz ${ }^{18}$ - tej monadycznej integralności odpowiada ze strony podmiotu doświadczenie „zatracanie się w dziele”"19, w którym niejako traci z oczu to, co na zewnątrz: problem zewnętrznej, faktycznej genezy dzieła ustępuje pola wewnętrznemu doświadczeniu jego (pozoru) bycianie-zrobionym. Tak należałoby więc chyba rozumieć ostatnie zdanie z przytoczonego fragmentu Teorii Estetycznej: gdy tylko artefakt chce budzić iluzję naturalności - rozbijając ściany swojej monady poprzez próbę quasi-naturalnego unaocznienia swojej genezy - zawodzi. Dla Adorna dzieło sztuki skazane jest na los mechanicznego słowika, a najlepsze, co może zrobić, to nie zapierać się tego.

To, co dotąd powiedziane, uzupełnić należałoby zapewne zwracając uwagę na dokonujące się w myśli frankfurtczyka udialektycznienie dziewiętnastowiecznego pojęcia piękna przyrody. Kantowskie ujęcie - konstytutywne zresztą w mniejszym lub większym stopniu dla późniejszej świadomości estetycznej aż do naszych czasów - zachowane jest jako nieredukowalne, ale i rozpoznane jako kulturowy konstrukt, na różne sposoby zapośredniczony społecznie. Przyroda jako obiekt doświadczenia estetycznego ukonstytuować się mogła dopiero dla człowieka wyrwanego z zasięgu jej bezpośredniej przemocy, człowieka panującego nad nią; co więcej, idea przyrody jako paradygmatu estetycznej wolności ukształtowała się jako swoisty rewers rosnącego urzeczowienia świata przez instrumentalną racjonalność nauk przyrodniczych. Tą myślą Adorno podejmuje spostrzeżenie Györgyego Lukácsa: przyroda, dla oświeconych aż do Kanta definiowana jako całokształt praw natury (prawidłowości i przewidywalności następujących zdarzeń) korespondujących $\mathrm{z}$ racjonalnością poznającego ją rozumu, w XIX wieku niepostrzeżenie przechodzi na przeciwstawną pozycję, skupiając w sobie wszystkie tendencje pozostające w opozycji do „mechanizacji, bezduszności, urzeczowienia”20. Natura w powyższym sensie - „zapośredniczony namiestnik

${ }^{18}$ Tamże, 327.

${ }^{19}$ Tamże, 326.

${ }^{20}$ György Lukács, Historia i świadomość klasowa. Studia o marksistowskiej dialektyce, tłum. Marek J. Siemek (Warszawa: PWN, 1988), 291-293. 
bezpośredniości”21 - sama jest jednak tylko obrazem, nie zaś rzeczywistością ${ }^{22}$ wzięta dosłownie, jako „anamnesis wolności” - wprowadza w błąd, „oczekując wolności po dawniejszym zniewoleniu"23 - to jest po pierwotnym stanie natury. Trudno tu ominąć jeszcze jedną ptasią reminiscencję Adorna: „Nie ma takiego wrażliwego człowieka, chroniącego w sobie coś z tradycji europejskiej, w którym by nie odezwało się wzruszenie na śpiew kosa po deszczu. A mimo to w śpiewie ptaków czai się coś straszliwego, ponieważ nie jest to śpiew, lecz posłuszeństwo sile, która je opanowuje"24. Również w przyrodzie, choć zupełnie inaczej niż w sztuce, charakterystyczne dla piękna znamię czegoś wyrosłego bez przymusu celowości jest jedynie pozorem, a nie istotą - nieuchwytnym błędnym ognikiem, niepewną obietnicą, niejasną zapowiedzią. Ostatecznie, transcendująca świat ludzki rola, jaką pięknu naturalnemu przyznał Kant, zakwestionowana w swej rzeczywistości, lecz zarazem zachowana w idei, utrzymuje się u Adorna jako czysto negatywna: jako „alegoria tego, co »poza« , mimo swego zapośredniczenia przez społeczną immanencję" 25 .

\section{VI}

Wróćmy raz jeszcze do słowika. O ile kantowska opowieść z celnością przekraczającą granice filozoficznych systemów trafia w nieredukowalne sedno doświadczenia piękna naturalnego jako obrazu - sięgnijmy po frazę Adorna - nieistniejącego pojednania, post-russowska baśń Andersena ubiera w słowa równie uniwersalne przekonanie - czy może marzenie - o możliwości uczestnictwa tworzącego człowieka-artysty w spontaniczności natury; topos dla którego paradygmatyczne pozostają takie gatunki jak pieśń czy improwizacja. Można by stąd uznać, że rysuje się tu coś w rodzaju alternatywy dwóch z konieczności ułomnych sposobów naśladowania piękna przyrody: bądź, jak w teorii Adorna, siłami racjonalnej organizacji artysta kształtuje wewnątrz zamkniętego dzieła-monady iluzję niecelowej celowości świata przyrody - lecz wtedy sam charakter "produkcji”

\footnotetext{
${ }^{21}$ Adorno, Teoria estetyczna, 114.

22 Tamże, 124.

23 Tamże, 123.

${ }^{24}$ Tamże.

25 Tamże, 127.
} 
dzieła pozostaje w sprzeczności ze spontanicznym wzrostem tworów natury bądź też postawić można na „unaturalnienie” samego procesu twórczego, naśladując spontaniczność powstawania-wzrostu piękna przyrody, rezygnując jednak z oczekiwań i kalkulacji co do charakteru powstałego tą drogą dzieła. Choć z koncepcji pozoru estetycznego zdaje się wynikać, że dla Adorna nie jest to godna uwagi alternatywa, jako że dla artysty możliwy i wartościowy pozostaje tylko pierwszy jej człon, warto postawić pytanie, co też frankfurtczyk ma nam do powiedzenia o tej drugiej możliwości. Czy da się u niego znaleźć echa russowskoandersenowskiej intuicji artysty przemawiającego „Z wewnątrz natury”, jako jej immanentna część? Co ciekawe, można odnieść wrażenie, iż w jego myśli istnieją dwie równoległe a zarazem istotnie różne odpowiedzi na to pytanie.

\section{VII}

Zapośredniczenie natury i społeczeństwa jest obustronne: świat ludzkich form i konwencji staje się „drugą przyrodą” (termin ukuty przez Lukácsa w jego Teorii Powieści), systemem obiektywnych, postrzeganych jako naturalne uwarunkowań. Cokolwiek Adorno jako filozof społeczny miałby do zarzucenia społeczeństwom „przedburżuazyjnym”, w oczywisty sposób uznaje on, iż istniały epoki, w których system przyjętych norm leżał na twórcy dość gładko i nieuciążliwie, by pozwalać mu na quasi-naturalną spontaniczność w granicach w pełni uwewnętrznionego języka, stylu czy konwencji ${ }^{26}$. Kosztem takiego stanu rzeczy zawsze jednak pozostawał fakt zamknięcia takiej twórczości w immanencji społecznej „drugiej przyrody”; fakt, że świadomość tworzącej jednostki nie sięga poza jej horyzont, ujemnie odbija się na zawartości prawdy dzieła, to kryterium zaś, wedle Adorna, „przesądza wszystko inne”27.

Możliwość tego rodzaju „drugiej naturalności” zmniejsza się wraz z rozwojem dziewiętnastowiecznego społeczeństwa mieszczańskiego. Sztuka nie ma problemu z widoczną „zrobionością”, póki wdziewa ją na siebie nieświadomie, jako oczywistą konwencję, część społecznej „drugiej przyrody”; dopiero sztuka XIX

\footnotetext{
${ }^{26}$ Por. np. uwagi Adorna o stosunku Mozarta do formy: Adorno, Teoria estetyczna, 257.

${ }^{27}$ Tamże, 386. O możliwości pozytywnie ocenianej identyfikacji z konwencją jako „drugiej naturalności” czy „drugiej bezpośredniości” najbardziej chyba wprost pisze Adorno w eseju Aldous Huxley i utopia, w: Adorno, Sztuka i sztuki. Wybór esejów, 237.
} 
wieku, stawiająca sobie za wzór przeciwstawioną światu konwencji spontaniczność natury, musi „ukrywać ślady swojej produkcji”, wyrodniejąc w „fantasmagorię"28. Stąd szczególne miejsce przyznane przez Adorna przełomowej w jego ujęciu twórczości Beethovena, która, przekroczywszy społeczną immanencję sztuki przedburżuazyjnej, pozoru estetycznego się nie wypiera, lecz tematyzuje go i czyni swoim przedmiotem.

Postępujący rozwój wewnętrzności odrywa jednostkę od świata społecznych form i konwencji demaskując je jako arbitralne, lecz osiągnięta wolność jest złudzeniem - fałszywą świadomością ukrywającą systemowe zniewolenie przez świat urzeczowionych stosunków społecznych. Proces erozji ponadjednostkowych norm artystycznych - stylów, gatunków, konwencji - jako „naturalnego środowiska” artysty opisuje Adorno zbiorczo pod hasłem „nominalizmu”. Osiągnięta tą drogą rzekoma swoboda twórcy jest złudna: samowolnie odrzucane bądź przyjmowane przez artystę konwencje stają się niewiążące i nieznaczące. Co dotychczas było „naturalnym” językiem sztuki, staje się problemem; ostatecznie, gdy artysta staje przed niewykonalnym dla jednostki zadaniem stworzenia własnego języka, spontaniczność podmiotu nieodwołalnie milknie ${ }^{29}$.

\section{VIII}

Niezależnie od tej zasadniczo negatywnej odpowiedzi Adorna, elementy dziewiętnastowiecznych intuicji quasi-przyrodniczej spontaniczności procesu twórczego znajdują na kartach Teorii estetycznej swoje istotne i oryginalne kontynuacje. Grupują się one zasadniczo w orbicie specyficznie adornowskiego pojęcia mimesis. Pojęcie to funkcjonuje w pismach frankfurtczyka jako odległe od klasycznego sensu terminu, w ścisłym natomiast związku ze z grubsza współczesnymi frankfurtczykowi ideami Rogera Caillois i Waltera Benjamina ${ }^{30}$, wskazujących na przyrodzoną człowiekowi tendencję do naśladowania, upodobniania się

${ }^{28}$ Adorno, Teoria estetyczna, 188.

${ }^{29}$ Por. Theodor W. Adorno, Parataksa. O późnej liryce Hölderlina, w: Theodor W. Adorno, O literaturze. Wybór esejów, red. Lech Burdecki, tłum. Anna Wołkowicz (Warszawa: Czytelnik, 2005), 77.

${ }^{30} \mathrm{O}$ osadzeniu tej linii myślenia o mimesis w tradycji myśli estetycznej i antropologicznej przełomu XIX i XX w. zob. Matthew Rampley, „Mimesis i alegoria. O Abym Warburgu i Walterze Benjaminie”, Przegląd Kulturoznawczy 2, nr 8 (2010): 54-74. 
czy tworzenia-odnajdywania podobieństw i powinowactw. Obaj autorzy podkreślają pierwotność zachowania mimetycznego zarówno w planie onto- jak i filogenetycznym, odnajdując je w charakterystycznych dla człowieka pierwotnego tendencjach do magicznej identyfikacji ze zwierzętami czy przedmiotami, zjawisku mimikry czy też dziecięcych zabawach opartych na naśladowaniu, odgrywaniu i utożsamianiu się.

Adorno koncepcję tę podejmuje i istotnie rozwija, czyniąc z mimesis jedno z fundamentalnych pojęć Teorii estetycznej. Poszukiwania jednego określonego znaczenia adornowskiej mimesis skazane są jednak na poważne trudności, frankfurtczyk posługuje się bowiem tym pojęciem szeroko i w rozmaitych kontekstach, co więcej, jak zauważa Fredric Jameson ${ }^{31}$, zawsze odnosząc się do niego jak do terminu wcześniej zdefiniowanego, czego wszakże w żadnym z pism nie czyni. Mowa jest u Adorna o różnych i rozmaicie wartościowanych formach mimesis, w tym związanych z rozmaitymi fazami historycznego rozwoju ludzkości (mimesis pierwotna - mimikra jako ślepy instynkt samozachowawczy i zdolność adaptacyjna, mimetyczna „magia homeopatyczna”, regresywna projekcja mimetyczna w micie jako pierwotnej formie dominacji człowieka nad przyrodą) czy pewnymi późniejszym zjawiskami („mimesis tego, co martwe” w pewnych tendencjach kultury późnego kapitalizmu; kicz jako „urzeczowiona mimesis”, „mimesis urzeczowienia" z kolei w prozie Kafki, sztuka szeroko rozumianego modernizmu jako „mimesis tego, co stwardniałe i wyobcowane”). Zarazem zauważyć daje się głębsza wieloznaczność: wiele sformułowań Adorna zdaje się wskazywać, że interpretacja mimesis wedle prostego schematu „upodobnienia do" nie tylko nie jest całkiem ścisła, ale i pomija istotną część charakterystyki terminu, bywa bowiem mimesis naśladowaniem, upodobnieniem się, nadaniem czemuś podobieństwa do siebie, rozpoznaniem "niezmysłowego powinowactwa”, „mimetycznym rozumieniem”, a nawet „byciem obrazem samego siebie”.

Stąd niektórzy komentatorzy, jak Martin Jay, uznają adornowską mimesis za termin nieusuwalnie wieloznaczny czy wręcz katachretyczny, wskazując, na przykład, jak w zależności od kontekstu bywa mimesis u Adorna wyzwalająca bądź

${ }^{31}$ Fredric Jameson, Late Marxism: Adorno, or, the persistence of the dialectic (London - New York: Verso, 1990), 64. 
wyobcowująca, progresywna bądź regresywna ${ }^{32}$. Wolno jednak zapytać, czy trudności te nie biorą się przypadkiem ze zbytniego utożsamiania samej mimesis z poszczególnymi jej formami oraz z sugestywności antropologicznych ujęć prehistorycznej czy mitycznej genezy zachowań mimetycznych. Tymczasem rozmaitość czy wręcz rozbieżność wymienianych przez Adorna postaci mimesis nie musi uniemożliwiać uchwycenia podstawowego sensu terminu (podobnie jak fakt, iż posłużmy się nieco trywialnym przykładem - trudno nam np. sensownie uzgodnić pojęcia „doświadczenia zmysłowego” „doświadczenia wolności”, „doświadczenia życiowego" i „doświadczenia naukowego" nie musi prowadzić do wniosku o braku określonego znaczenia słowa „doświadczenie”) - jeśli tylko przyjąć, że chodzi tu rzeczywistość bardziej pierwotną od pojęć, jakich chcielibyśmy użyć do jej definiowania, a leżącą u podłoża rozmaitych wymienianych przez Adorna form mimesis jako ich wspólne jądro. Rzec by można - być może nieco nadużywając ścisłych terminów logicznych - że rozmaite użycia terminu przez Adorna składają się wspólnie na coś w rodzaju wieloczłonowej definicji kontekstowej o cechach definicji ostensywnej. Podobna intencja zdaje się przyświecać Shierry’emu W. Nicholsenowi $^{33}$, kiedy wskazuje, że dochodzenie do zrozumienia adornowskiej mimesis przypomina nieco poznawanie nieznanego słowa bez pomocy słownika, poprzez napotykanie go w kolejnych kontekstach, które ostatecznie owocuje zrozumienie głębszym, niż dać może jakakolwiek zwarta definicja, choć niekoniecznie dającym się wyrazić pojęciowo (obraz ten zaczerpnął zresztą Nicholsen z tekstu Adorna Esej jako forma, gdzie służyć miał za ilustrację benjaminowskiej koncepcji „myślenia konstelacjami”’34).

${ }^{32}$ Martin Jay, „Mimesis and Mimetology. Adorno and Lacoue-Labarthe”, w: The semblence of subjectivity: essays in Adorno's Aesthetic theory, red. Tom Huhn, Lambert Zuidervaart (Cambridge, MA: MIT Press, 1997), 45. Tę perspektywę zasadniczo przyjmuje Rafał Michalski pisząc o „rodzinnym podobieństwie” różnych form mimesis, a za nim Rafał Czekaj; zob: Rafał Michalski, Antropologia mimesis. Studium myśli Waltera Benjamina i Theodora W. Adorna (Nowa Wieś: Wydawnictwo Rolewski, 2008), 135-136; Rafał Czekaj, Krytyczna teoria sztuki Theodora W. Adorna (Kraków: Universitas, 2013), 91. Praca Michalskiego jest najobszerniejszym i najbardziej gruntownym omówieniem różnych form i funkcji mimesis w pismach Adorna.

${ }^{33}$ Shierry Weber Nicholsen, „Aesthetic Theory’s Mimesis of Walter Benjamin”, w: The semblence of subjectivity, 83 .

${ }^{34}$ Adorno, Esej jako forma, w: Adorno, Sztuka i sztuki. Wybór esejów, 89. 
W kolejnych akapitach niniejszego tekstu podejmuję strategię Nicholsena na własny użytek i w nieco ograniczonym zakresie - uwypuklając te cechy mimesis, lokujące się w orbicie procesu twórczego i doświadczenia estetycznego (jak to zostanie pokazane, sfery te, rozpatrywane pod interesującym mnie kątem, przenikają się), które pozwalają na rekonstrukcję koncepcji Adorna naświetlającą jej związki z omawianymi tu tradycjami XIX-wiecznej myśli estetycznej.

\section{IX}

Zacznijmy od doświadczenia estetycznego, którego mimesis pozostaje niezbywalnym momentem. „[...] to, co z istoty mimetyczne, oczekuje zachowania mimetycznego. Jeżeli dzieła sztuki nie naśladują niczego poza sobą, to i nie zrozumie ich nikt, kto ich nie naśladuje” ${ }^{\text {" }}$. Na tego, kto dzieła "nie odtwarza, postępując za jego własną dyscypliną” wiersz czy obraz „patrzy pustymi oczami””36. Mimesis nie jest tu określoną przedmiotowo (przez kategorię wierności odwzorowania czy podobieństwa) imitacją czy naśladowaniem, lecz raczej definiowanym podmiotowo procesem włączenia-się-w czy dostosowania-się-do. Pewnym, choćby i jednostronnym modelem takiego „rozumienia przez naśladowanie” wydawać się może obraz gry albo zabawy, której sens (i sensowność) zrozumieć można jedynie włączając się w nią. Nie tylko niekoniecznie umieć musimy pojęciowo określić znaczenie tego, co się dzieje, ale usiłowanie takie może wręcz utrudnić nam uczestnictwo; subiektywne poczucie rozumienia jest tu skutkiem i przychodzi już po włączeniu się w proces. Podobnie jest $\mathrm{z}$ konwencją czy zwyczajem, które, jako arbitralne, nie podlegają zrozumieniu w kategoriach sensu, przyczyny czy też celu - możliwe jest jedynie naśladowanie ich aż do momentu, gdy staną się druga naturą człowieka. W obu przypadkach zrozumienie jest nie tyle pojęciowym opanowaniem czy też przyswojeniem sobie czegoś, co raczej włączeniem siebie w obręb czegoś większego, zawierającym w sobie moment zawieszenia, rozbicia czy zignorowania oporu stawianego przez racjonalną część podmiotu i rzucenia się niejako na ślepo w to, co - na razie jeszcze - obce. Przez niezaangażowanego obserwatora tego rodzaju zrozumienie - nieprzekazywalne przecież pojęciowo - zawsze może być nazwane raczej ogłupieniem czy zaślepieniem. Dwuznaczności tej nie waha

\footnotetext{
${ }^{35}$ Adorno, Teoria estetyczna, 231 i 221-223.

${ }^{36}$ Tamże, 221.
} 
się Adorno odnieść do sztuki jako takiej, wskazując na absurdalność, jaką przejawia sztuka dla osób estetycznie niewrażliwych, jako konieczny rewers jej zagadkowego - ergo wymagającego mimetycznego zaangażowania - charakteru ${ }^{37}$. Ciekawe, że to „mimetyczne rozumienie” kojarzyć się może - jak najsłuszniej - z teorią gier językowych Ludwiga Wittgensteina. Do tegoż filozofa zdaje się - świadomie bądź nie - nawiązywać Adorno, gdy reinterpretuje tradycyjnie rozumianą językowość muzyki i pisze: „rozumieć język to interpretować go, rozumieć muzykę to wykonywać ją"38.

Dotknięty w tym ostatnim zdaniu mimetyczny aspekt sztuk performatywnych uważa Adorno za signum sztuki jako takiej. Mimetyczne działanie jest ślepym „zdaniem się” (ten czasownik pojawia się u Adorna nagminnie w kontekście mimesis) na impulsy płynące spoza podmiotu: Adorno odwołuje się do obrazu dobrego wykonawcy, który grając dany utwór czuje się w najmniejszym szczególe prowadzony przez to, co odczytywane z partytury - takiego rodzaju jest nie tylko wykonywanie, ale i tworzenie oraz rozumienie muzyki, podobnie jak i innych sztuk $^{39}$. Immanentne postępowanie sztuki ma w sobie „coś z różdżkarstwa”, idzie „na ślepo, po omacku”, „tym wierniejsze, im bardziej dla siebie nieprzejrzyste”" Tendencja mimetyczna sztuki to ślepe zdanie się na impuls, sam impuls jednakże nie ślepy bynajmniej, lecz prowadzący po określonej „linii ruchu” tego, co naśladowane $e^{41}$.

Klasycznym już w myśli Waltera Benjamina i tą drogą pojawiającym się w pismach Adorna typem zachowania mimetycznego jest memorie involontaire, przypomnienie mimowolne, mające swe literackie źródło w proustowskim motywie magdalenki - zmysłowego bodźca, zapomnianego, lecz zachowanego w pamięci ciała, który jako jedyny zdolny jest rzeczywiście przywołać i uobecnić przeszłość. Cielesny impuls uruchamia głęboko dialektyczny proces, w którym nie tylko to, co najgłębiej znane i najbardziej własne, ukazuje się zarazem jako nowe - bo wyrwane z nieświadomości zapomnienia - ale i to, co najbardziej osobiste, przygodne i fragmentaryczne ukazuje się w postaci wyrwanego spod władzy czasu

\footnotetext{
${ }^{37}$ Tamże.

${ }^{38}$ Theodor W. Adorno, Music, Language and Composition, w: Essays on Music, red. Richar Leppert, tłum. Susan Gillespie (Berkeley - Los Angeles - London: Universisty of California Press, 2002), 115.

${ }^{39}$ Adorno, Teoria estetyczna, 230.

${ }^{40}$ Tamże, 211.

${ }^{41}$ Tamże, 229-230.
} 
bytu obiektywnego. Choć Benjamin nie waha się nazwać owoców tego przeżycia „uzyskaniem obrazu samego siebie” i „zapanowaniem nad własnym doświadczeniem" ${ }^{\prime 2}$, to $\mathrm{w}$ większej zgodzie z kierunkiem myśli Adorna pozostaniemy chyba ujmując mimetyczny ruch memoire involontaire jako swoiste rozmycie granic podmiotu poprzez projekcję tego, co subiektywne w obiektywność. W Teorii estetycznej frankfurtczyk przywołuje ideę zapośredniczonego przez doświadczenie zmysłowe wspomnienia mimowolnego, by pokazać, jak mimetyczny charakter sztuki przybrać może postać odwrócenia klasycznego pojęcia mimesis - nie tyle już naśladowania rzeczywistości, co raczej swoistego wezwania rzeczywistości do naśladowania sztuki. Mimetyczny impuls staje się anamnesis: sztuka, na kształt memoire involontaire, zmysłowym bodźcem budzi w samej głębi empirii przeczucie-pamięć tego, co „poza”: przypomnienie tego, co sprzed wszelkiej świadomej pamięci, okazuje się tyleż samo przeczuciem możliwości tego (i marzeniem o tym), co jeszcze nie istniejące ${ }^{43}$.

Ta mimetyczna dynamika wspomnienia mimowolnego, torem niezmysłowego powinowactwa prowadząca, bez udziału świadomej decyzji, od cielesnego bodźca do wewnętrznego doświadczenia kwestionującego uświadomione granice tożsamości podmiotu (jak ujmuje to Adorno, memorie involontaire „czepia się zmysłowości, wywołując jej przeciwieństwo”) wskazuje na jeden jeszcze istotny aspekt mimesis, jakim jest jej uwikłanie w materię, w fizjologię, w tworzywo. Sztuka nie może odrzucić oporu materii i doświadczenia jego przełamywania jako czegoś przygodnego i zewnętrznego; miarą jej wartości jako „rozwinięcia prawdy” jest także to, na ile jej moment mimetycznego „zdania-się-na” jest również - czy przede wszystkim - zdaniem się na impulsy materii. Adornowska „materia” to zaś przede wszystkim dialektyczna opozycja dla po heglowsku pojmowanego ducha: wszystko co (jeszcze) nieprzetworzone, nietknięte ręką twórcy. W tym sensie może być nią zarówno fizyczny aspekt wykonywania muzyki lub tworzywo rzeź-

\footnotetext{
${ }^{42}$ Walter Benjamin, O kilku motywach u Baudelaire’a, tłum. Adam Lipszyc, w: Walter Benjamin, Konstelacje. Wybór tekstów, red. Adam Lipszyc (Kraków: Universitas, 2012), 266.

${ }^{43}$ Adorno, Teoria Estetyczna, 242-243, 248.
} 
biarza, jak i forma, konwencja, styl czy idiom: wszystko, co staje się materią kształtującego działania podmiotu ${ }^{44}$. Mimetyczność procesu twórczego to dopuszczenie do głosu tego, co nie-podmiotowe, co przychodzące z zewnątrz.

Aktywna w mimetycznym ruchu dialektyka subiektywności i obiektywności odsyła zresztą nie tylko do świata natury, ale i do wspólnoty ludzkiej: przez idiosynkratyczne impulsy podmiotu przebija się kolektywna pamięć zbiorowości, prowadząc je ku obiektywizacji osiąganej w formie dzieła ${ }^{45}$.

\section{$\mathbf{X}$}

Wymowa przywołanych fragmentów zbiega się, po pierwsze, we wskazaniu, iż trudno o coś bardziej mylnego niż łączenie adornowskiej mimesis z celowym i zamierzonym naśladownictwem, upodobnieniem czy upodobnieniem-się; idzie tu raczej o bezwiedny, mimowolny i przedracjonalny pociąg, w którym identyfikacja-powinowactwo podmiotu $\mathrm{z}$ tym, co inne, może być zarówno postulowane, nadane, przebudzone jak i rozpoznane jako już istniejące - a właściwie kategorie te zlewają się w jedno. W pewnym sensie także kategorie podmiotu i przedmiotu (lub przedmiotów) trzeba odrzucić jako nierelewantne: mimesis nie łączy się z określonym kształtem relacji, a mówiąc ściślej, samą jej relacyjność pojmować należałoby chyba jedynie jako pewna metaforę czy przybliżenie. Rzecz nie w tym „między czym a czym” „do czego” czy też „przez kogo” mimesis zachodzi czy też się dokonuje; czy mówimy o mimetycznym tworzeniu czy rozumieniu, upodobnieniu-czegoś czy upodobnieniu-się, czy też po prostu „byciu obrazem samego siebie" - chodzi raczej o sam sposób istnienia niestwardniałej w podmiot - jak można by to chyba, podejmując adornowski idiom, ująć - niewyobcowanej ze świata świadomości.

W Dialektyce oświecenia, wspólnym dziele Adorna i Maxa Horkheimera, mimesis utożsamiona jest $\mathrm{z}$ freudowskim popędem śmierci: „tendencja, której

${ }^{44} \mathrm{O}$ uwikłaniu procesu twórczego w materię pisze Adorno najchętniej na przykładzie muzyki. Zob. Theodor W. Adorno, Towards a Theory of Musical Reproduction. Notes, a Draft and Two Schemata, red. Henri Lonitz, tłum. Wieland Hoban (Cambridge-Malden, MA: Polity Press, 2006), 149; oraz Adorno, Aldoux Huxley i utopia, 245.

${ }^{45}$ Adorno, Teoria estetyczna, 240. 
przezwyciężenie jest znakiem rozwoju; by zatracić się w otaczającym świecie, zamiast dzień w dzień z nim się borykać, skłonność, by dać sobie spokój, zatonąć w naturze. Freud nazywa to popędem ku śmierci, Caillois - mimetyzmem" ${ }^{\prime 46}$. Dlatego, biorąc nawet poprawkę na rodzaj wieloznaczności mimesis, o którym była już mowa, obstawać należałoby przy konstytutywnym dla mimesis napięciu pomiędzy bierną, quasi-fizjologiczną, pokrewną popędowi dynamiką mimetycznego impulsu rozpoznania/utożsamienia-się-z a jego twórczym i kształtującym charakterem, o którym wnosić można z przywoływanych wyżej fragmentów Teorii estetycznej. Paradoksalność, na jaką skazany jest przedsięwzięty w ramach kategorii instrumentalnego rozumu opis współistniejących w mimesis momentów twórczości i bierności, najlepiej chyba obrazuje przywoływany już obraz wykonywania muzyki: co dla zewnętrznego obserwatora jawi się jako twórcza interpretacja wykonawcy, dla niego samego jest wynikiem pełnego podporządkowania się, czy, po Adornowsku, „zdania się” na to, co odczytywane z partytury. Tezę Adorna, która stwierdza, że wykonanie utworu muzycznego jest - czy winno być - „imitacją nieobecnego oryginału”47, rozszerzyć należałoby na dzieło sztuki jako takie; jeśli zaś pisze Adorno gdzie indziej, iż są dzieła „obrazem samych siebie”, rozumieć należy przez to dokładnie to samo. Uchwycić sens adornowskiej mimesis to ująć ją w oderwaniu od konkretnych kształtów relacji, choć wewnętrznie zachowującą swą relacyjną treść.

Jeśli zaś chcielibyśmy obecny $\mathrm{w}$ ostatnim przywołanym fragmencie trop „poddania się” i „rezygnacji”, skojarzony przez autorów z freudowskim tanatosem, rozumieć jako przynależny mimesis jako takiej, nie zaś jedynie jednej z jej form, należałoby chyba ująć go przede wszystkim jako równoznaczny z zachwianiem wszechwładzy podmiotu jako siły organizującej i samoorganizującej, subsumującej rzeczywistość pod siatkę pojęć, a tym samym określającej swoje granice w opozycji do poznawanego w ten sposób świata ${ }^{48}$. Tą drogą wchodzimy w orbitę epistemologicznego aspektu mimesis, jasno zaznaczanego przez frankfurtczyka

${ }^{46}$ Theodor W. Adorno, Max Horkheimer, Dialektyka Oświecenia, tłum. Małgorzata Łukasiewicz (Warszawa: Wydawnictwo Instytutu Filozofii i Socjologii PAN, 1994), 250.

${ }^{47}$ Tamże, 116.

${ }^{48}$ Por. Vladimir Safatle, „Mirrors without images. Mimesis and recognition in Lacan and Adorno", Radical Philosophy 2006, nr 139: 14. 
w słowach: „tym [...], do czego apeluje zachowanie mimetyczne, jest telos poznania, blokowany przez kategorie tegoż poznania" ${ }^{\prime 9}$. Kantowskie konotacje wybrzmiewają w tym zdaniu expressis verbis, kategorialne kształtowanie rzeczywistości przez podmiot musi być uchylone, a narzędziem tego uchylenia staje się mimesis. Jej naśladowczo-identyfikacyjne aspekty pozwalają zrozumieć, w jaki sposób to zawieszenie ukonstytuowanej podmiotowości nie skutkuje rozpłynięciem się jednostki w tym, co inne, lecz nawiązaniem nowego (a właściwie najbardziej pierwotnego) rodzaju - „sympatycznych” w źródłowym sensie słowa - relacji ze światem; trop memoire involontaire z kolei zdaje się pokazywać, jak w procesie tym ujawnia się głębokie pokrewieństwo jednostki z tym, co inne, a jej głęboka tożsamość odsłania się jako szersza niż wąsko zakreślone granice ukonstytuowanej podmiotowości. Zachowanie mimetyczne ujawnia się jako residuum pierwotnej więzi łączącej człowieka ze światem, przywołując niejako przedhistoryczny stan poprzedzający wytyczenie ścisłej granicy pomiędzy podmiotem a przedmiotem ${ }^{50}$. Jako „fizjologiczna niejako przed-forma ducha" ${ }^{51}$, pozostaje także mimesis uprzednia względem ostrego rozróżnienia poznania od działania - jest poznaniem czynnym i zaangażowanym, wchodząc $w$ bezpośredni aktywny kontakt $\mathrm{z}$ tym co poznawane, choć $\mathrm{w}$ innym sensie pozostaje bierna, dopuszczając to, co obce, na własnych jego prawach, wstrzymując się od momentu pojęciowego panowania, zdając się na rzecz samą ${ }^{52}$. Wedle Adorna, mimesis jest nieodzownym momentem każdego aktu poznawczego - pozbawione przymieszki owego uprzedniego, quasicielesnego porozumienia jednostki ze światem czysto pojęciowe poznanie „degraduje się w tautologię". To „śmiercionośne” rozdzielenie ratio i mimesis może być

${ }^{49}$ Adorno, Teoria estetyczna, 100.

${ }^{50}$ Por. tamże, 203. Adorno używa nie całkiem jasnego zwrotu „po tej stronie (diesseits) utrwalonego przeciwstawienia podmiotu i przedmiotu” - wydaje się, iż „po tej stronie” odnosi się nie do granicy podmiot-przedmiot, lecz do czasowej (czy quasi-czasowej) granicy oddzielającej stan utrwalenia rzeczonego przeciwstawienia od stanu, gdy nie było ona jeszcze utrwalone. W tym duchu interpretuje to np. najnowszy przekład angielski, parafrazując „diesseits” jako „distant from” - por. Theodor W. Adorno, Aesthetic Theory, tłum. Robert Hullot-Kentor (Minneapolis: University of Minnesota Press, 2002), 110.

${ }^{51}$ Adorno, Teoria estetyczna, 208.

${ }^{52}$ Simon Jarvis nazywa to postulatem prymatu rzeczy. Por. Simon Jarvis, Adorno. Crtical Introduction (New York: Routledrge, 1998), 181-184. Co ciekawe, Matthew Rampley kojarzy tak rozumianą mimesis z pojawiającym się w estetyce końca XIX wieku pojęciem empatii jako aktywnego momentu poznania: swoistej mimetycznej projekcji podmiotu na poznawaną rzeczywistość, odkrywającej-powołującej w niej związki sensu i wartości; zob. Rampley, „Mimesis”, 56-57. 
jednak odwołane w sztuce ${ }^{53}$; tutaj podmiot może stanąć naprzeciw innego „oddzielony, a przecież nie całkiem oddzielony" ${ }^{\prime 4}$.

\section{XI}

Echa romantycznych czy postrussowskich idei artysty uczestniczącego $\mathrm{w}$ spontaniczności natury pobrzmiewają $\mathrm{w}$ adornowskiej koncepcji mimesis czysto i wyraźnie: w motywie „zdania-się-na” jako zawieszeniu świadomej celowości działania twórcy - pozwoleniu, by przemówiło przez niego coś innego niż on sam; w sugestii, iż na tej drodze przekroczyć da się aporię klasycznej estetyki, w jaki sposób to, co subiektywnie stworzone, okazać się może obiektywnie wiążącym (jawiącym jako - by sięgnąć raz jeszcze po frazę Adorna - po-prostu-istniejące, na kształt tworów przyrody); wreszcie w osiągniętym w działaniu mimetycznym rozmyciu granic pomiędzy twórcą, tym co naśladowane i tym co tworzone, korespondującym $z$ analogicznym charakterem natury i jej tworów, określanych przez Kanta, jak pamiętamy, jako agere i efectus raczej niż facere i opus.

Baczniej jednakże niż na owe korespondencje zwrócić trzeba w tym momencie uwagę na ich ograniczenia, nie pozwalające na uznanie mimesis za organ $\mathrm{z}$ ducha russowskiej utopii utraconego stanu natury. Stosunek adornowskiej koncepcji do intuicji romantyków pozostaje zasadniczo w pełnej analogii do przekształcenia, jakiego w Teorii estetycznej uległo kantowskie ujęcie pięknej natury, pozostawione, jak pamiętamy, jako czysto negatywne. Także mimesis, jako siła zakorzenionej w niepamiętnej, przed-podmiotowej archaiczności, odsunięta zostaje poza horyzont dostępny naiwnej idylli szczęśliwego człowieka pierwotnego. O dwuznacznym charakterze archaicznych form mimesis najbardziej wprost pisze frankfurcki filozof na kilku stronach Teorii estetycznej poświęconych problemowi artystycznego wyrazu. Ekspresja, będąc mimetycznym momentem sztuki par excellance, z konieczności jednak pozostać musi „najszczelniej” odgrodzona od rzeczywistości poza dziełem, stając się wyrazem samym w sobie - już nie wyrazem czegoś ani czyimś. Tym samym zaś, pisze Adorno, dokonuje się „historyczny wy-

\footnotetext{
${ }^{53}$ Adorno, Teoria estetyczna, 600.

${ }^{54}$ Tamże, 100.
} 
rok nad mimesis jako zachowaniem archaicznym: że ona, praktykowana bezpośrednio, nie jest poznaniem; że to, co czyni sobie podobnym, nie staje się podobne, że ingerencja przez mimesis nie udawała się"55. Archaiczne, dosłowne w swej relacyjności postaci mimesis nie są więc pierwotne w sensie źródłowe; już prędzej można by je nazwać formami zdegenerowanymi (czy może raczej - jeszcze nieoczyszczonymi), stąd zaś linia interpretacyjna, po której postępowaliśmy, pozbywając się stopniowo jej relacyjnych wyobrażeń, okazuje się zarazem jej historyczną linią rozwojową. Pierwotność idealnej mimesis, jako ściśle odróżnionej od rzeczywistych kształtów jej form archaicznych, pozostaje czysto negatywną. Gdy frankfurtczyk dotyka tego idealnego obrazu mówiąc o wyrazie sztuki jako „bezmownej mowie” ewokującej „prehistorię podmiotowości” - tożsamość nie opartą na odgraniczeniu od tego, co inne, uprzednią względem identycznościowej konstrukcji podmiotu $^{56}$ - nie idzie mu o realne formy prehistoryczne, lecz o to co pozaczasowo źródłowe, archetypiczne, i wciąż - choćby w przeczuciu - obecne w podmiocie.

„Szczelność”, o której była mowa powyżej, odgradzająca mimetyczną ekspresję sztuki od rzeczywistości, to nic innego jak szczelność postępowania technicznego dzieła, chroniąca mimesis przed wciąż jej zagrażającym upadkiem w formy regresywne. $\mathrm{W}$ tym miejscu trop mimesis jako echo słowika $\mathrm{z}$ baśni Andersena domyka się z wątkiem pozoru estetycznego jako kontynuacją problemu słowika kantowskiego: mimesis i instrumentalna racjonalność zapośredniczają się w dziele sztuki i wzajemnie korygują. Zapośredniczenia tego nie należy jednak pojmować jedynie jako współistnienia w dziele dialektycznie przeciwstawnych momentów, sięga ono głęboko, do samego rdzenia procesu twórczego, w którym nawet decydujące o racjonalności dzieła momenty jak poczucie formy okazują się mimetycznie „ślepe” - niejako prowadzone po omacku - a mimetyczny impuls pozwala sobą arbitralnie dysponować ${ }^{57}$. Tak wyjaśnia się ostatecznie podwójna odpowiedź frankfurtczyka na pytanie o możliwość quasi-naturalnej spontaniczności sztuki: jako mimesis pozostaje ona jedynie momentem, który bez korektury racjonalno-

55 Tamże, 204.

56 „Takie bycie sobą, którego z interdependencji bytu nie wydobywa dopiero identyfikujące spojrzenie". Tamże, 207.

57 Tamże, 211, por. także 82. 
ści nieuchronnie popada w regresywne utożsamienie $\mathrm{z}$ „drugą przyrodą” urzeczowionych stosunków społecznych czy w nie mniej regresywne uprzedmiotowienie piękna naturalnego.

Opis problematyczności, jaką w myśli frankfurckiego filozofa ujawnia idea uczestniczącego w spontaniczności natury artysty, domknąć można przywołując zawarte w Teorii estetycznej uwagi dotyczące pojęcia geniuszu. Była już mowa o tym, iż jego funkcję w obrębie Krytyki władzy sądzenia określa Adorno jako „miejsce schronienia” dla wszystkiego, czego nie dopuszczała logika systemu królewieckiego filozofa. Taką koncepcję geniuszu postrzega Adorno w ścisłej łączności z tym, co sam opisuje jako mimetyczny moment procesu twórczego - świadczą o tym uwagi przyznające geniuszowi działanie „na kształt natury”, ów „dialektyczny węzeł” obecny w paradoksalnym pojęciu działania mimetycznego: „to, co nieszablonowe, nie powtarzane, swobodne, co zarazem wywołuje wrażenie konieczności [...] nowe, mocą swej nowości, wywołuje wrażenie, iż zawsze tu już było" ${ }^{58}$. Problem jednak w tym, że genialność - jak pisze Adorno „z nieobliczalnymi następstwami” - zarezerwował Kant ,jedynie dla podmiotu, nie zwracając uwagi na obcość tego właśnie momentu wobec Ja"59. Otworzyło to drogę do swoistego zawłaszczenia geniuszu przez podmiot w późniejszej idealistycznej filozofii niemieckiej, która rozdymając ów podmiot w samostanowiącego ducha zwiększyła jeszcze kantowski rozziew między człowiekiem a naturą, przenosząc zarazem wszystko, co istotne, na stronę tego pierwszego. Konsekwencją było heglowskie wyparcie idei piękna naturalnego z obszaru estetyki, a ostatecznie „religia sztuki” i idolatria geniuszu jako wyjątkowej jednostki ${ }^{60}$. Wedle Adorna, problem ten można śledzić na planie społecznym jako swoistą ideologizację pojęcia, które ostatecznie przybrało postać dialektycznego dopełnienia rosnącego urzeczowienia stosunków społecznych: „uprzywilejowanemu geniuszowi zostaje zastępczo przypisane to, czego realność powszechnie ludziom odmawia"61.

${ }^{58}$ Tamże, 312-313.

${ }^{59}$ Tamże, 311. O twórczości genialnej jako „wypływając z samej natury twórcy” pisze Kant wprost w Antropologii w ujęciu pragmatycznym, tłum. Ewa Drzazgowska, Paulina Sosnowska (Warszawa: Wydawnictwo Instytutu Filozofii i Socjologii PAN, 2005), 289. Choć warto zauważyć, iż samo użycie terminu „natura” wskazuje na aporetyczność, na jaką skazany jest omawiany problem rozważany w obrębie pojęć późnego oświecenia.

${ }^{60}$ Por. Adorno, dz. cyt., 114-115.

${ }^{61}$ Tamże, 312. 
Uwzględniając moment mimesis jako immanentny postępowaniu sztuki element pre-racjonalny i pre-podmiotowy, Adorno wyklucza tego rodzaju uzurpację; właściwa geniuszowi spontaniczność - pisze frankfurtczyk - ma w sobie „coś mimowolnego", zawiera w sobie "moment obcości wobec Ja pod naciskiem rzeczy" $^{\prime 2}$. W samym niejako rdzeniu procesu twórczego dochodzi do mimetycznej kapitulacji podmiotu, nie przekreślającej jego tożsamości, lecz dopuszczającej na równych prawach do głosu to, co inne, co obce, co przychodzące z zewnątrz. Stąd spontaniczności procesu twórczego nie sposób już utożsamić ani z wolnością suwerennego i nieskrępowanego działania „z głębi własnego bytu”, jak w zideologizowanym pojęciu geniuszu późnego wieku XIX, ani też z realizacją naiwnego post-russowskiego marzenia o znoszącym granice utożsamieniu jednostki z samą naturą, nieskrępowanie objawiającą się w twórczości artysty. Te dwa ideologiczne - jak zapewne powiedziałby Adorno - obrazy są faktycznie zwierciadlanymi odbiciami, a różnica między nimi jest w dużej mierze pozorna. O celności kantowskiego ujęcia decyduje fakt, iż mimo wprowadzenia zapośredniczającego naturę z podmiotem pojęcia geniuszu pozostawia napięcie pomiędzy nimi nierozwiązane, uznając jednocześnie wyższość piękna naturalnego i podtrzymując granicę oddzielającą przedmiot (naturę) od podmiotu jako nieprzekraczalną. Ujęcie Adorna wnosi w tak postawioną alternatywę rozpoznanie tyleż nieusuwalnie problematycznego, co historycznie - a właściwie pre-historycznie - ukształtowanego charakteru samej podmiotowości, interpretowanej w myśli frankfurtczyka w sposób łączący w sobie krytyczną reinterpretację elementów kantowskich (kategorialne kształtowanie rzeczywistości jako wyobcowująca przemoc) i heglowskich (wyniesienie ducha ponad przyrodę jako ideologiczne uroszczenie) z późniejszymi koncepcjami instrumentalnej racjonalności (Max Weber) i represyjnie konstruowanej osobowości (Sigismunt Freud). Ostatecznie mimesis, jako moment nie opartego na przemocy powinowactwa człowieka $z$ tym, co inne, represjonowany i wypierany w procesie konstrukcji racjonalnego podmiotu, nie odsyła więc do mitycznego stanu pierwotnej harmonii, ani tym bardziej nie restauruje jej niczym deux ex machina, będąc tym raczej, co, zagubione w rozwoju cywilizacyjnym, pozostało nigdy nie oczyszczone i nie zrealizowane, a co zarówno okazać się może konieczną korektą instrumentalnego rozumu, jak i samo takiej korekty wymaga. Znalazłszy ostatnie schronienie w sztuce, mimesis z konieczności dzieli

${ }^{62}$ Tamże, 309-310. 
z nią moment nierzeczywitości - pozoru, któremu jednak zarazem zawdzięcza ocalenie tak od archaicznych jak i nowoczesnych form regresji.

Tym czyściej - rzec by można - rozbrzmiewać może w sztuce swobodny śpiew żywego ptaka, anamnetycznie unaoczniając możliwość pojednania podmiotu z tym, co od niego inne, im nieodwołalniej zaprzecza mu quasi-technologiczne postępowanie dzieła, odgradzając się szczelnie od tego, co istniejące, złotą skorupą słowika mechanicznego.

\section{Bibliografia}

Adorno, Theodor W., Max Horkheimer. Dialektyka Oświecenia. Tłum. Małgorzata Łukasiewicz. Warszawa: Wydawnictwo Instytut Filozofii i Socjologii PAN, 1994.

Adorno, Theodor W. Aesthetic Theory. Tłum. Robert Hullot-Kentor. Minneapolis: University of Minnesota Press, 2002.

Adorno, Theodor W. Ästhetische Theorie. Berlin: Suhrkamp, 1973.

Adorno, Theodor W. Essays on Music. Red. Richard Leppert. Tłum. Susan Gillespie. Berkeley Los Angeles - London: Universisty of California Press, 2002.

Adorno, Theodor W. O literaturze. Wybór esejów. Red. Lech Burdecki. Tłum. Anna Wołkowicz. Warszawa: Czytelnik, 2005.

Adorno, Theodor W. Sztuka i sztuki. Wybór esejów. Red. Karol Sauerland. Tłum. Krystyna Krzemień-Ojak. Warszawa: PIW, 1990.

Adorno, Theodor W. Teoria estetyczna. Tłum. Krystyna Krzemieniowa. Warszawa: PWN, 1994. Adorno, Theodor W. Towards a Theory of Musical Reproduction. Notes, a Draft and Two Schemata. Red. Henri Lonitz. Tłum. Wieland Hoban. Cambridge-Malden, MA: Polity Press, 2006.

Benjamin, Walter. Konstelacje. Wybór tekstów. Red. Adam Lipszyc. Przeł. Adam Lipszyc, Anna Wołkowicz. Kraków: Universitas, 2012.

Celenza, Anna Harwell. Hans Christian Andersen and Music: The Nightingale Revealed. London - New York: Ashgate, 2017.

Czekaj, Rafał. Krytyczna teoria sztuki Theodora W. Adorna. Kraków: Universitas, 2013.

Jameson, Fredric. Late Marxism: Adorno, or, the persistence of the dialectic. London - New York: Verso, 1990.

Jarvis, Simon. Adorno. Crtical Introduction. New York: Routledrge, 1998.

Jay, Martin. „Mimesis and Mimetology. Adorno and Lacoue-Labarthe”. W: The semblence of subjectivity: essays in Adorno 's Aesthetic theory. Red. Tom Huhn, Lambert Zuidervaart, 29-53. Cambridge, MA: MIT Press, 1997.

Kant, Immanuel. Antropologia w ujęciu pragmatycznym. Tłum. Ewa Drzazgowska, Paulina Sosnowska. Warszawa: Wydawnictwo Instytutu Filozofii i Socjologii PAN, 2005. 
Kant, Immanuel. Krytyka władzy sądzenia. Tłum. Jerzy Gałecki. Warszawa: PWN, 1986.

Langguth, Jerome. „Kant Nightingale: Aesthetic Disappointment as Loss of Interpretive Richness", http://www.academia.edu/4055373/Kants_Nightingale Dostęp 17.08.2020. Lukács, György. Historia i świadomość klasowa. Studia o marksistowskiej dialektyce. Tłum. Marek J. Siemek. Warszawa: PWN, 1988.

Michalski, Rafał. Antropologia mimesis. Studium myśli Waltera Benjamina i Theodora W. Adorna. Nowa Wieś: Wydawnictwo Rolewski, 2008.

Nicholsen, Shierry Weber. Aesthetic Theory's Mimesis of Walter Benjamin. W: The semblence of subjectivity: essays in Adorno 's Aesthetic theory. Red. Tom Huhn, Lambert Zuidervaart, 54-91. Cambridge, MA: MIT Press, 1997.

Rampley, Matthew. „Mimesis i alegoria. O Abym Warburgu i Walterze Benjaminie”. Przegląd Kulturoznawczy 2, nr 8 (2010): 54-74.

Safatle, Vladimir. „Mirrors without images. Mimesis and recognition in Lacan and Adorno”. Radical Philosophy 2006, nr 139: 9-19.

Schiller, Friedrich. Listy o estetycznym wychowaniu człowieka i inne rozprawy. Tłum. Irena Krońska, Jerzy Prokopiuk. Warszawa: Czytelnik, 1972.

\section{Summary}

Kant's and Andersen's Nightingale and Adorno's Mimesis. An Essay on the 18th- and 19th-century Prehistory of Some Motifs in Aesthetic Theory

The essay focuses on some aspects of Theodor W. Adorno's aestethic theory viewed as a specific kind of reinterpretation of - as well as discussion with - the Kantian and romantic ideas of natural beauty. The article's axis is the motif of the nightingale's singing as a paradigm of natural beauty used by Kant's in his Critic of the Power of Judgement and its reinterpretation in Hans Christian Andersen's well-known fairy-tale, both addressed in the same paragraph of Adorno's study. The reconstruction of Adorno's concept of mimesis as an impulse towards the non-subjective, combining spontaneity with involuntariness, reactivity with creative and shaping character, and ultimately questioning the rational construction of the subject by dividing it from what is different, allows to show how and to what extent the early romantic vision of an artist participating in the spontaneity of nature could be preserved in Adorn's aesthetic thought - the same time, however, denied by the indelible artifacticity - semblance character - of the work of art.

Keywords: Immanuel Kant; Theodor W. Adorno; natural beauty; mimesis; aesthetic semblance 


\section{Zusammenfassung}

\section{Die Nachtigall von Kant, die Nachtigall von Andersen und Adornos Mimesis. Ein Essay auf den Spuren der Vorgeschichte von einigen Fäden der Ästhetischen Theorie im 18. und 19. Jahrhundert}

Der Essay konzentriert sich auf einigen Aspekten der ästhetischen Theorie von Theodor W. Adorno als einer eigenartigen Neuinterpretation von Kantischen und romantischen Ideen des Naturschönen. Die Achse der durchgeführten Reflexion ist das Motiv des Gesanges einer Nachtigall als ein Paradigma der Spontaneität des Naturschönen, das von Kant in Kritik der Urteilskraft eingeführt wurde sowie seine Neuinterpretation in dem bekannten Märchen von Hans Christian Andersen, beide in demselben Kapitel der Schrift von Adorno aufgerufen. Der Begriff der Mimesis bei Adorno wird als Impuls für etwas außerhalb des Subjekts rekonstruiert. Dieser Impuls, der in sich die Spontaneität mit dem Unwillkürlichen, die Reaktivität mit schöpferischem und kreativem Charakter verbindet, hinterfragt letztendlich eine rationale Konstruktion des Subjekts, die durch Abgrenzung des Anderen erfolgt. Die Rekonstruktion lässt erkennen, wie - und in welchem Maß - die frühromantische Vision des Künstlers, der an der Spontanität der Natur teilnimmt, im ästhetischen Konzept Adornos beibehalten werden konnte, indem sie gezwungenermaßen mit der sie verneinenden Artefaktivität gleichzeitig bestand - dem Zug des Scheins, der jedem Kunstwerk immanent ist.

Schlüsselworte: Immanuel Kant, Theodor W. Adorno, das Naturschöne, Mimesis, ästhetischer Schein

Information about Author:

JAKUB CHACHULSKI, PhD, The Institute of Art of the Polish Academy of Sciences, address for correspondence: ul. Długa 28, PL 00-238 Warszawa; e-mail: jakub.chachulski@ispan.pl 